\title{
Application of Electrocoagulation Process for Dairy Wastewater Treatment
}

\author{
Edris Bazrafshan, ${ }^{1}$ Hossein Moein, ${ }^{2}$ Ferdos Kord Mostafapour, ${ }^{1}$ and Shima Nakhaie ${ }^{1}$ \\ ${ }^{1}$ Health Promotion Research Center and Department of Environmental Health Engineering, Zahedan University of Medical Sciences, \\ Zahedan, Iran \\ ${ }^{2}$ Zahedan University of Medical Sciences, Zahedan, Iran
}

Correspondence should be addressed to Hossein Moein; hmoein26@yahoo.com

Received 24 August 2012; Revised 7 December 2012; Accepted 10 December 2012

Academic Editor: Ana Moldes

Copyright (C) 2013 Edris Bazrafshan et al. This is an open access article distributed under the Creative Commons Attribution License, which permits unrestricted use, distribution, and reproduction in any medium, provided the original work is properly cited.

Dairy industry wastewater is characterized by high biochemical oxygen demand $\left(\mathrm{BOD}_{5}\right)$, chemical oxygen demand (COD), and other pollution load. The purpose of this study was to investigate the effects of the operating parameters such as applied voltage, number of electrodes, and reaction time on a real dairy wastewater in the electrocoagulation process. For this purpose, aluminum electrodes were used in the presence of potassium chloride as electrolytes. It has been shown that the removal efficiency of COD, $\mathrm{BOD}_{5}$, and TSS increased with increasing the applied voltage and the reaction time. The results indicate that electrocoagulation is efficient and able to achieve $98.84 \%$ COD removal, $97.95 \% \mathrm{BOD}_{5}$ removal, $97.75 \%$ TSS removal, and $>99.9 \%$ bacterial indicators at $60 \mathrm{~V}$ during $60 \mathrm{~min}$. The experiments demonstrated the effectiveness of electrocoagulation techniques for the treatment of dairy wastewaters. Finally, the results demonstrated the technical feasibility of electrocoagulation process using aluminum electrodes as a reliable technique for removal of pollutants from dairy wastewaters.

\section{Introduction}

Food processing industries cause severe environmental problems because of generation of strong wastewater characterized by high biological oxygen demand $\left(\mathrm{BOD}_{5}\right)$ and chemical oxygen demand (COD) [1]. Among the food industries, the dairy industry is the most polluting in terms of volume of effluent generated as well as in terms of its characteristics too, generating about $0.2-10 \mathrm{~L}$ of effluent per liter of processed milk [2].

The dairy industry is generally considered to be the largest source of food processing wastewater in many countries. Water is used throughout all steps of the dairy industry, including cleaning, sanitization, heating, cooling, and floor washing; naturally, the industry's need for water is huge [3]. In general, wastes from the dairy processing industry contain a high concentration of organic material such as proteins, carbohydrates and lipids, high $\mathrm{BOD}_{5}$ and $\mathrm{COD}$, and high concentrations of suspended solids and suspended oil grease. The $\mathrm{BOD}_{5}$ concentrations for dairy factory wastewaters can vary widely depending on the season or product cycle. For instance, it has been reported that cheese factories have $\mathrm{BOD}_{5}$ ranging from 588 to $5000 \mathrm{mg} / \mathrm{L}$, whereas factories producing cream have $\mathrm{BOD}_{5}$ in the range of $1200-4000 \mathrm{mg} / \mathrm{L}$ [4].

All of these require specialized treatments to prevent or minimize environmental problems. Dairy wastewaters (DWs) are also characterized by wide fluctuations in flow rates, related to discontinuity in the production cycles of different products $[5,6]$. Therefore, dairy wastewater treatment is very important from environment and water requirement point of view for dairy industry.

Dairy wastewaters are generally treated usually using biological methods such as activated sludge process, aerated lagoons, aerobic bioreactor, trickling filters, sequencing batch reactor (SBR), upflow anaerobic sludge blanket (UASB) reactor, upflow anaerobic filters, and biocoagulation, [4, 710]. Aerobic biological processes are high energy intensive, whereas anaerobic treatment of dairy wastewater reflects very poor nutrient removal, and effluents treated by anaerobic biological processes need additional treatment $[6,11]$. On 
TABLE 1: Characteristics of the raw dairy wastewater used for this study.

\begin{tabular}{lccc}
\hline Parameters & $\begin{array}{c}\text { Raw wastewater } \\
\text { Mean } \pm \text { S.D. }\end{array}$ & $\begin{array}{c}12 \mathrm{~h} \\
\text { settled wastewater } \\
\text { Mean } \pm \text { S.D. }\end{array}$ & $\begin{array}{c}\text { Permissive levels } \\
\text { (Iran standard) }\end{array}$ \\
\hline Number of samples & 24 & 24 & - \\
Total COD $(\mathrm{mg} / \mathrm{L})$ & $7855.25 \pm 703.05$ & $6114.25 \pm 74.52$ & 60 \\
Total BOD $(\mathrm{mg} / \mathrm{L})$ & $3486.3 \pm 235.17$ & $2919.3 \pm 45.27$ & 30 \\
Total suspended solids $(\mathrm{mg} / \mathrm{L})$ & $1724.17 \pm 149.14$ & $734.43 \pm 22.13$ & 60 \\
Total coliforms $(\mathrm{TCs})$ & $4.39 \times 10^{6} \pm 2.5 \times 10^{5}$ & $3.53 \times 10^{6} \pm 1.1 \times 10^{5}$ & 1000 \\
Fecal coliforms $(\mathrm{FCs})$ & $3.27 \times 10^{6} \pm 1.3 \times 10^{5}$ & $2.75 \times 10^{6} \pm 7.2 \times 10^{4}$ & 400 \\
Conductivity $(\mu \mathrm{S} / \mathrm{cm})$ & $8010 \pm 1300$ & $8073.67 \pm 59.53$ & - \\
$\mathrm{pH}$ & $7.65 \pm 0.02$ & $7.24 \pm 0.07$ & $6.5-8.5$ \\
\hline
\end{tabular}

the other hand, the physical/chemical methods that have been proven to be successful are coagulation/flocculation $[12,13]$.

In the recent years, investigations have been focused on the treatment of wastewaters using electrocoagulation (EC) because of the increase in environmental restrictions on effluent wastewater. Electrocoagulation (EC) is an electrochemical method for treating polluted water which has been successfully applied not only for the treatment of soluble or colloidal pollutants, such as slaughterhouse wastewater [14], vegetable oil refinery [15], dairy industry wastewater [16, 17], slaughterhouse wastewater [18], nitrate-bearing wastewater [19], wastewaters containing heavy metals, and pesticides and phenolic compounds [20-25], but also drinking water for fluoride and humic acid removal [26-28].

Electrocoagulation involves the generation of coagulants in situ by dissolving electrically either aluminium or iron ions from aluminum or iron electrodes, respectively. The metal ions generation takes place at the anode, and hydrogen gas is released from the cathode. The hydrogen gas would also help to float the flocculated particles out of the water. The electrodes can be arranged in a monopolar or bipolar mode. The materials can be aluminium or iron in plate form or packed form of scraps such as steel turnings and millings $[29,30]$.

An examination of the chemical reactions occurring in the electrocoagulation process shows that the main reactions occurring at the electrodes (aluminum electrodes) are

$$
\begin{gathered}
\text { Anode }: \mathrm{Al} \longrightarrow \mathrm{Al}_{(\text {aq })}^{3+}+3 \mathrm{e} \\
\text { Cathode }: 3 \mathrm{H}_{2} \mathrm{O}+3 \mathrm{e} \longrightarrow 3 / 2 \mathrm{H}_{2}+3 \mathrm{OH}^{-}
\end{gathered}
$$

The cathode may also be chemically attacked by $\mathrm{OH}^{-}$ions generated during $\mathrm{H}_{2}$ evolution at high $\mathrm{pH}$ [31]:

$$
2 \mathrm{Al}+6 \mathrm{H}_{2} \mathrm{O}+2 \mathrm{OH}^{-} \longrightarrow 2 \mathrm{Al}(\mathrm{OH})_{4}{ }^{-}+3 \mathrm{H}_{2}
$$

$\mathrm{Al}^{3+}{ }_{(\text {aq) }}$ and $\mathrm{OH}^{-}$ions generated by electrode reactions (1) react to form various monomeric species such as $\mathrm{Al}(\mathrm{OH})^{2+}$, $\mathrm{Al}(\mathrm{OH})_{2}{ }^{+}, \mathrm{Al}_{2}(\mathrm{OH})_{2}{ }^{4+}$, and $\mathrm{Al}(\mathrm{OH})_{4}{ }^{-}$and polymeric species such as $\mathrm{Al}_{6}(\mathrm{OH})_{15}{ }^{3+}, \mathrm{Al}_{7}(\mathrm{OH})_{17}{ }^{4+}, \mathrm{Al}_{8}(\mathrm{OH})_{20}{ }^{4+}$, and $\mathrm{Al}_{13} \mathrm{O}_{4}(\mathrm{OH})_{24}{ }^{7+}, \mathrm{Al}_{13}(\mathrm{OH})_{34}{ }^{5+}$, which transform finally into $\mathrm{Al}(\mathrm{OH})_{3}$ according to complex precipitation kinetics [32].
Freshly formed amorphous $\mathrm{Al}(\mathrm{OH})_{3}$ "sweep flocs" have large surface areas which are beneficial for a rapid adsorption of soluble organic compounds and trapping of colloidal particles. These flocs polymerize as

$$
n \mathrm{Al}(\mathrm{OH})_{3} \longrightarrow \mathrm{Al}_{n}(\mathrm{OH})_{3 n}
$$

and they are easily removed from aqueous medium by sedimentation and by $\mathrm{H}_{2}$ flotation. On the other hand, the aluminum hydroxide flocs normally act as adsorbents and/or traps for pollutants. Therefore, they would eliminate them from the solution $[21,30]$.

Secondary anodic reactions occur also during electrocoagulation process; for example, in neutral and acidic chloride solutions, native and free chlorine and hypochlorite are formed which are strong oxidants $[33,34]$.

$$
\begin{aligned}
2 \mathrm{Cl}^{-} & \longleftrightarrow \mathrm{Cl}_{2}+2 \mathrm{e} \\
2 \mathrm{H}_{2} \mathrm{O} & \mathrm{O}_{2}+4 \mathrm{H}^{+}+4 \mathrm{e} \\
\mathrm{Cl}_{2}+\mathrm{H}_{2} \mathrm{O} & \longleftrightarrow \mathrm{HClO}+\mathrm{H}^{+}+\mathrm{Cl}^{-} \\
\mathrm{HClO} & \longleftrightarrow \mathrm{ClO}^{-}+\mathrm{H}^{+}
\end{aligned}
$$

In this study, real dairy industry wastewater has been treated using aluminum electrodes in a batch reactor. This study elucidates the effects of parameters such as applied voltage, reaction time, and number of electrodes on the $\mathrm{BOD}_{5}$ and $C O D$ removal efficiencies. Information regarding the electrical energy consumption and electrode consumption are also included to provide an estimation of the cost of pollutants removal by an electrocoagulation system.

\section{Experimental}

2.1. Dairy Wastewater. The wastewater used in this work was taken from the local dairy factory in Iran (Sistan and Baluchestan province), with 25000 (mean value) kg milk per day processing capacity. Although the quality of the effluent was variable, it was colored milk, and typical characteristics of the raw dairy wastewater are presented in Table 1. Samples were collected in polypropylene bottles, shipped cold and kept at $4^{\circ} \mathrm{C}$ before use. The length of the storage before 
starting experiments varied from one day to six weeks. The effluent has been sampled at different times during this study, and the initial characteristics varied with time (Table 1). This effluent initially contained high concentrations of soluble and suspended materials.

2.2. Setup and Procedure. In each run, wastewater (supernatant) after $12 \mathrm{~h}$ settling time was poured into the electrocoagulation cell. All experiments were performed in a bipolar batch reactor (Figure 1), with six aluminum electrode connected in parallel. Only the outer electrodes were connected to the power source, and anodic and cathodic reactions occurred on each surface of the inner electrode when the current passed through the electrodes. The internal size of the cell was $15 \mathrm{~cm} \times 15 \mathrm{~cm} \times 25 \mathrm{~cm}$ with an effective volume of $2000 \mathrm{~cm}^{3}$. The volume $(V)$ of the solution of each batch was $2 \mathrm{~L}$. The active area of each electrode (plate) was $14 \mathrm{~cm} \times 20 \mathrm{~cm}$ (submerged area) with a total area of $280 \mathrm{~cm}^{2}$. The distance between electrodes was $2 \mathrm{~cm}$. A power supply having an input of $220 \mathrm{~V}$ and variable output of $0-60 \mathrm{~V}$ (10, $20,30,40,50$, and $60 \mathrm{~V}$ ) with maximum current of 5 ampere was used as direct current source. The temperature of each system was maintained at $25 \pm 2^{\circ} \mathrm{C}$. Different samples of 100-150 $\mathrm{mL}$ were taken at $15 \mathrm{~min}$ intervals for up to $1 \mathrm{~h}$ and filtered before being analysed to determine $\mathrm{BOD}_{5}$, COD, TSS, total coliforms, fecal coliforms, and other parameters. During the runs, the reactor unit was stirred at $150 \mathrm{rpm}$ by a magnetic stirrer to allow the chemical precipitate to grow large enough for removal. During electrocoagulation, an oxide film formed at the anode. In order to overcome electrode passivation at the anode, the electrodes were rinsed in diluted $\mathrm{HCl}$ solution $(5 \% \mathrm{v} / \mathrm{v})$ after each experiment and rinsed again with tap water and finally weighted. Also, the electrodes reweighted to calculate sacrificial electrode consumptions. These weights are used in the calculations of the total operating cost. In addition, the electrical energy consumed per unit volume of treated wastewater has been calculated for different experimental conditions. All analyses were conducted in duplicate for reproducibility of the experimental results, and all of the data in the figures and tables were the average ones.

2.3. Analytica. $\mathrm{COD}, \mathrm{BOD}_{5}$, total suspended solids (TSSs), conductivity, total and fecal coliforms, and $\mathrm{pH}$ determinations were determined according to the standard methods (APHA, 2005). COD was measured using COD reactor and direct reading spectrophotometer (DR/5000, HACH, USA). Five-day biological oxygen demand $\left(\mathrm{BOD}_{5}\right)$ was determined by the manometric method with a respirometer OxiTop system (WTW). The $\mathrm{pH}$ and conductivity were adjusted to a desirable value using $\mathrm{NaOH}$ or $\mathrm{H}_{2} \mathrm{SO}_{4}$ and $\mathrm{NaCl}$ and measured using a $\mathrm{pH}$ meter model UB-10 (Ultra Basic, US) and a conductivimeter model Cond 3110, respectively.

\section{Results and Discussion}

The effects of parameters such as applied voltage and reaction time have been evaluated under specific conditions for a constant temperature.

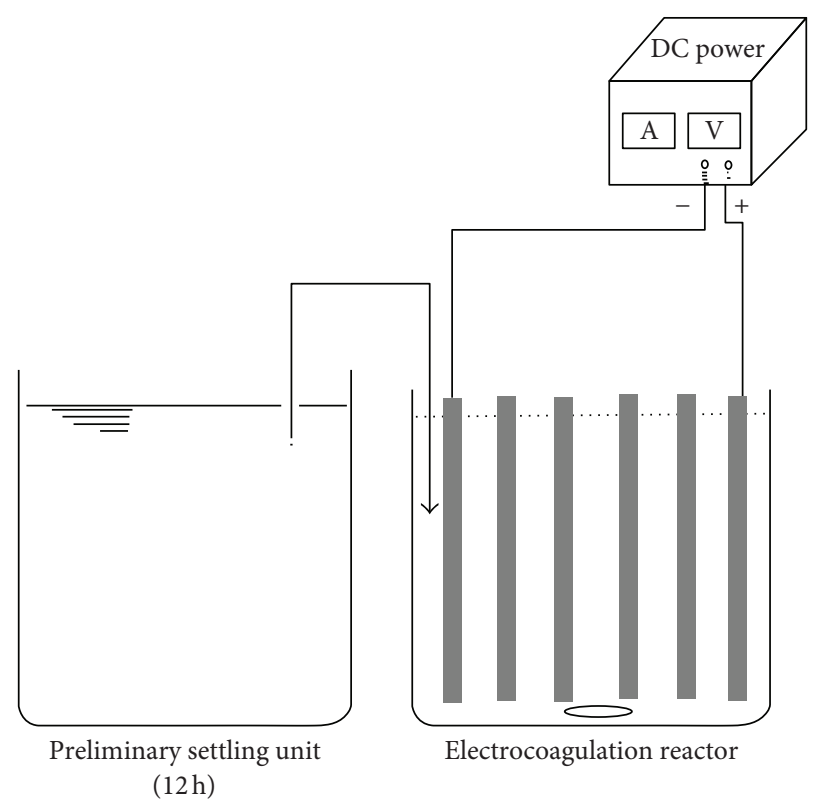

FIGURE 1: Experimental setup of electrocoagulation unit.

3.1. Wastewater Characterization. Table 1 presents the real dairy wastewater characteristics prior to any treatment, after $12 \mathrm{~h}$ settling time and the guidelines from Iran for effluent discharge in the sewage urban works. The values of the pollution parameters were lowered after $12 \mathrm{~h}$ of preliminary settling time. Also, the comparison of these values showed that the $\mathrm{COD}, \mathrm{BOD}_{5}$, and the concentration of TSS, were much greater than those recommended by Iran. Consequently, the dairy effluent needed to be treated before discharge.

3.2. Effect of Preliminary Settling Time. Preliminary settling process is a natural treatment method that requires no chemical addition. Although some workers realized the importance of the natural settling process, there is little information available in the literature on the effect of the preliminary settling time on pollutants removal capacity.

In this study, the raw dairy wastewater was allowed to settle in a preliminary settling tank before the electrocoagulation process. The process had an effect on $\mathrm{BOD}_{5}, \mathrm{COD}$, TSS, and total and fecal coliforms removals on the first $12 \mathrm{~h}$. COD was reduced from $7855.25 \pm 703.05$ to $6114.25 \pm$ $74.52 \mathrm{mg} / \mathrm{L}$ (resulting in more than $22 \%$ COD removal efficiency), whereas $\mathrm{BOD}_{5}$ was reduced in the wastewater from $3486.3 \pm 235.17$ to $2919.3 \pm 45.27 \mathrm{mg} / \mathrm{L}$ (resulting in $16 \%-17 \%$ $\mathrm{BOD}_{5}$ removal efficiency). Furthermore, TSS concentration was reduced from $1724.17 \pm 149.14$ to $734.43 \pm 22.13 \mathrm{mg} / \mathrm{L}$ (resulting in more than 57\% TSS removal efficiency). Similar results were reported by Amuda and Alade [35].

Also, data revealed that the effluent of the settling unit is characterized by high load of organic matter. The ratio $\mathrm{BOD}_{5} / \mathrm{COD}$ of approximately 0.48 indicates that $50 \%$ of the COD of this wastewater is easily able to be degraded by biological treatment. Nevertheless, the remainder COD is high, 
TABLE 2: Influence of electrocoagulation process using aluminum electrodes on dairy wastewater quality parameters (mean values).

\begin{tabular}{|c|c|c|c|c|c|}
\hline \multirow[b]{2}{*}{ Applied voltage (V) } & \multicolumn{5}{|c|}{ Quality parameters of treated effluent after electrocoagulation unit } \\
\hline & $\begin{array}{c}\mathrm{COD} \\
(\mathrm{mg} / \mathrm{L})\end{array}$ & $\begin{array}{l}\mathrm{BOD}_{5} \\
(\mathrm{mg} / \mathrm{L})\end{array}$ & $\begin{array}{c}\text { TSS } \\
(\mathrm{mg} / \mathrm{L})\end{array}$ & $\begin{array}{c}\text { TC } \\
(\mathrm{MPN} / 100 \mathrm{~mL})\end{array}$ & $\begin{array}{c}\text { FC } \\
(\mathrm{MPN} / 100 \mathrm{~mL})\end{array}$ \\
\hline 10 & 2405.96 & 892.2 & 372.43 & 1115480 & 476850 \\
\hline 20 & 1390.99 & 484.47 & 298.18 & 209329 & 89925 \\
\hline 30 & 1143.98 & 432.55 & 167.89 & 59340 & 38500 \\
\hline 40 & 681.74 & 379.35 & 131.76 & 57892 & 38225 \\
\hline 50 & 649.94 & 310.27 & 26.73 & 49420 & 18975 \\
\hline 60 & 70.92 & 43.45 & 16.52 & 361 & 28 \\
\hline
\end{tabular}

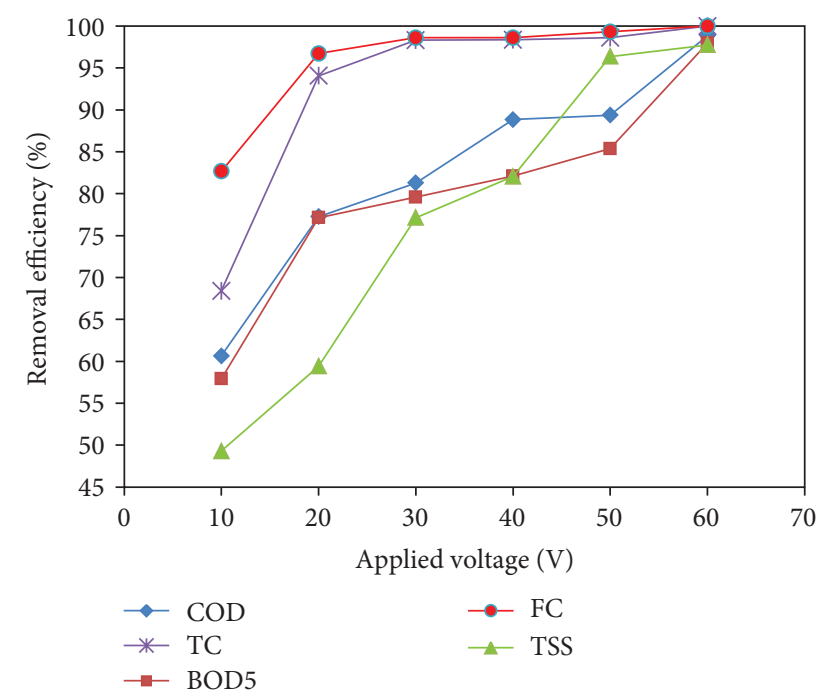

FIGURE 2: Effect of applied voltage on pollutants removal from dairy wastewater (reaction time $=60 \mathrm{~min})$.

which indicates the necessity of an efficient physicochemical treatment for this wastewater.

3.3. Effect of Electrocoagulation Process. Electrocoagulation processes a direct current source between metal electrodes immersed in wastewater. The electrical current causes the dissolution of metal electrodes commonly iron and aluminum into wastewater. The dissolved metal ions, at an appropriate $\mathrm{pH}$, can form wide ranges of coagulated species and metal hydroxides that destabilize and aggregate the suspended particles or precipitate and adsorb dissolved contaminants $[29,36]$.

The effect of applied voltage and reaction time on electrocoagulation process of real dairy wastewater treatment were determined. The results of effect of operating parameters on pilot scale electrocoagulation process are shown in Table 2 and Figure 2. The applied voltage is expected to exhibit a strong effect on electrocoagulation process, especially on the $\mathrm{BOD}_{5}$ abatement and COD removal: the higher the voltage, the shorter the treatment. The supply of voltage to the electrocoagulation system determines the amount of $\mathrm{Al}^{3+}$ ion released from the respective electrodes and the quantity of resulting coagulant. Thus, more $\mathrm{Al}^{3+}$ ions get dissolved into the solution, and the formation rate of $\mathrm{Al}(\mathrm{OH})_{3}$ is increased. Also, it is well known that electrical potential not only determines the coagulant dosage rate but also the bubble production rate and size and the flocs growth which can influence the treatment efficiency of the electrocoagulation process $[37,38]$.

Figure 2 and Table 2 illustrate the effect of applied voltage on pollutants removal efficiency at $\mathrm{pH}$ of 7.24. Removal efficiencies of more than $97 \%$ were achieved after $60 \mathrm{~min}$ electrocoagulation for all voltages $(10-60 \mathrm{~V})$. Also, it is clear that by increasing electrical potential from 10 to $60 \mathrm{~V}$, the pollutants concentration in the effluent decreased significantly. As an example, COD concentration has decreased from 6114.25 to $2405.96 \mathrm{mg} / \mathrm{L}$ (approximately $60.6 \%$ COD removal efficiency) after electrocoagulation process with electrical potential of $10 \mathrm{~V}$. Again, by increasing electrical potential to $60 \mathrm{~V}$, the COD concentration in the effluent decreased to $70.9 \mathrm{mg} / \mathrm{L}$ in $60 \mathrm{~min}$ (approximately $98.8 \% \mathrm{COD}$ removal efficiency). Also, $\mathrm{BOD}_{5}$ concentration has reduced from 2919.3 to $892.2 \mathrm{mg} / \mathrm{L}$ (nearly $57.9 \% \mathrm{BOD}_{5}$ removal efficiency) after electrocoagulation process with electrical potential of $10 \mathrm{~V}$, and by increasing electrical potential to $60 \mathrm{~V}$, the $\mathrm{BOD}_{5}$ concentration in the effluent declined to $43.45 \mathrm{mg} / \mathrm{L}$ in $60 \mathrm{~min}$ (around $98 \% \mathrm{BOD}_{5}$ removal efficiency). The same trend was observed for TSS concentration in wastewater after electrocoagulation process, so the removal efficiency increased from $49.29 \%$ at electrical potential of $10 \mathrm{~V}$ to $97.75 \%$ at electrical potential to $60 \mathrm{~V}$. Furthermore, as can be seen from Figure 2 and Table 2, the removal efficiency of bacterial indicators (TC and FC) is very high, and efficiency was raised with increase in applied voltage from 10 to $60 \mathrm{~V}$. Maximum removal efficiency (>99.9\%) was obtained in applied voltage $60 \mathrm{~V}$, and thus the effluent quality was reached to permissive levels (lower than 1000 and 400 for TC and FC, resp.), and hence from the viewpoint of microbial aspects, discharge of this effluent to environment is safe. Also, minimum removal efficiency occurred in the lowest electrical potential $(10 \mathrm{~V})$. This is ascribed to the fact that at high voltage, the amount of oxidized aluminum increased, resulting in a greater amount of precipitate for the removal of pollutants. In addition, it was demonstrated that bubbles density increases and their size decreases with increasing 
current density [39], resulting in a greater upwards flux and a faster removal of pollutants and sludge flotation. In fact, the most important mechanisms for removal of pollutants in this process are rapid adsorption of soluble organic compounds and trapping of colloidal particles in "sweep flocs" $\left(\mathrm{Al}(\mathrm{OH})_{3}\right)$. The results of this study are in agreement with the results of researches done by Nouri et al. [24] on zinc and copper removal from aqueous solutions by aluminum electrodes, Bazrafshan et al. [22] on the efficiency of EC with iron and aluminum electrodes in removal of chromium, Mansoorian et al. [40] on nickel removal from aqueous solutions by EC process with iron-rod electrodes, Njiki et al. [41] on mercury removal from water by EC process with aluminum and iron electrodes, Bazrafshan et al. [28] on humic acid removal from underground waters by EC process using iron electrodes, Bazrafshan et al. [25] on the efficiency of EC with aluminum and iron electrodes in removal of phenol, and also Bazrafshan et al. [27] on the efficiency of EC with aluminum and iron electrodes in removal of fluoride from aqueous solutions. Nevertheless, Bayar et al. [42] reported that increase in the current density does not cause an expected removal efficiency increase; on the contrary, it can cause a relatively negative effect on it. Also, a similar trend was seen in the study of Holt et al. [38].

Figures 3, 4, 5, 6, and 7 represent the effect of reaction time on pollutants removal from dairy wastewater at various applied voltages. Theoretically, based on Faraday's law, duration of electrolysis affects the amount of released electrode in a system with aluminum electrodes and determines the amount of produced $\mathrm{Al}^{3+}$ from this electrodes [43]. EC process includes two steps, destabilization and accumulation. The first step is usually short, and the second one is relatively long. With increase in reaction time, both energy and electrode consumption increase and this shows that reaction time is a very important parameter due to affecting the cost effectiveness of EC process in polluted waters [44].

In the present study, as it can be seen from Figures $3-7$, more than $50 \%$ of wastewater quality parameters were removed in the first minutes (only $15 \mathrm{~min}$ ), especially for applied voltages $30,40,50$, and $60 \mathrm{~V}$, while in later minutes, the percentage of removal was low. Also, more than $50 \%$ removal efficiency of COD and $\mathrm{BOD}_{5}$ was obtained at all applied voltages at $15 \mathrm{~min}$ (Figures 3 and 4). Furthermore, as the time of electrolysis was increased, comparable increases in the pollutants removal rate were observed for all applied voltages. On the other hand, for a given time, the removal efficiency increases significantly with an increase in applied voltages. As an example, after 60 min of electrolysis (Figure 3), it can be seen that $60.65 \%$, $77.25 \%, 81.29 \%, 88.85 \%, 89.37 \%$, and $98.84 \%$ of COD were removed for applied voltages of $10,20,30,40,50$, and $60 \mathrm{~V}$, respectively. Also, as the applied voltage was increased, the required time for the electrocoagulation process decreased. This was ascribed to the fact that at high current, the amount of oxidized metal increased, resulting in a greater amount of precipitate for the removal of pollutants. Similar trends were observed for other quality parameters of dairy wastewater.

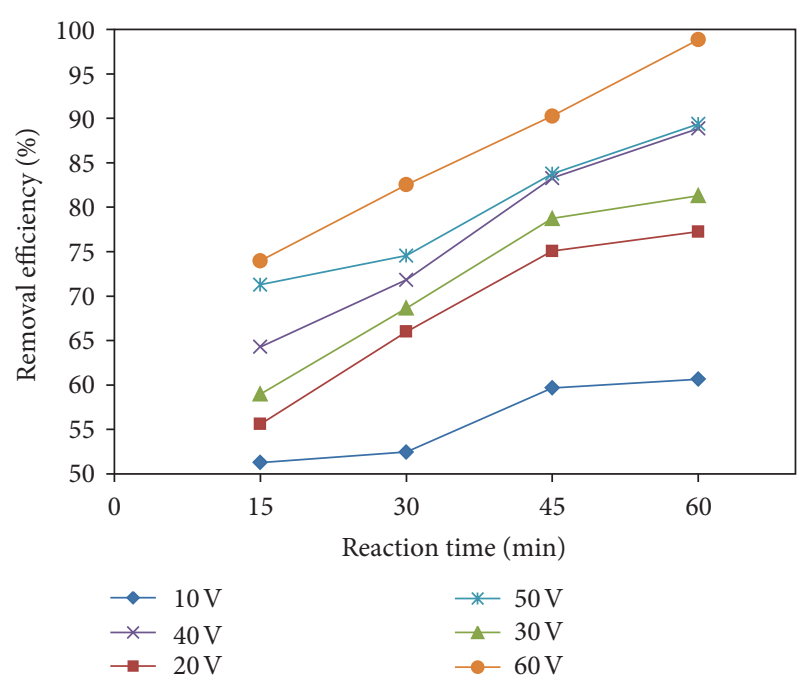

FIGURE 3: Effect of reaction time on COD removal from dairy wastewater at various applied voltages.

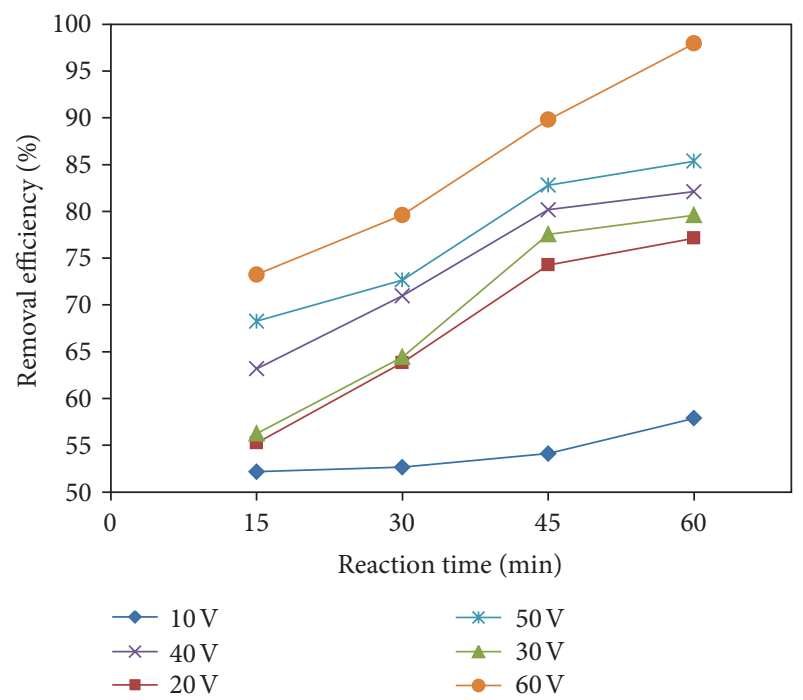

FIGURE 4: Effect of reaction time on $\mathrm{BOD}_{5}$ removal from dairy wastewater at various applied voltages.

The results of this study is in accordance with the results of researches done by Wan et al. [45] on removal of arsenic from water by using EC, Ugurlu et al. [46] on the removal of lignin and phenol from paper mill effluents by EC, and also Merzouk et al. [47] on removal of turbidity and separation of heavy metals using electrocoagulationelectroflotation technique.

3.3.1. Electrical Energy and Electrode Consumption. Electrical energy consumption is a very important economical parameter in the electrocoagulation process. Therefore, for the same operating conditions, after $60 \mathrm{~min}$ of electrocoagulation, consumption of energy and aluminum electrode were determined, that is, represented in Table 3. It can be understood from Table 3 that electrical energy and electrode 
TABLE 3: Electrical energy and electrode consumption during electrocoagulation process (reaction time $=60 \mathrm{~min}$ ).

\begin{tabular}{lccccrr}
\hline & \multicolumn{5}{c}{ Applied voltage V } \\
& 10 & 20 & 30 & 40 & 50 & 60 \\
\hline Energy consumption (Kwh/L) & 0.012 & 0.027 & 0.074 & 0.080 & 0.089 \\
Electrode consumption (g) & 0.249 & 0.585 & 1.841 & 1.457 & 2.312 \\
\hline
\end{tabular}

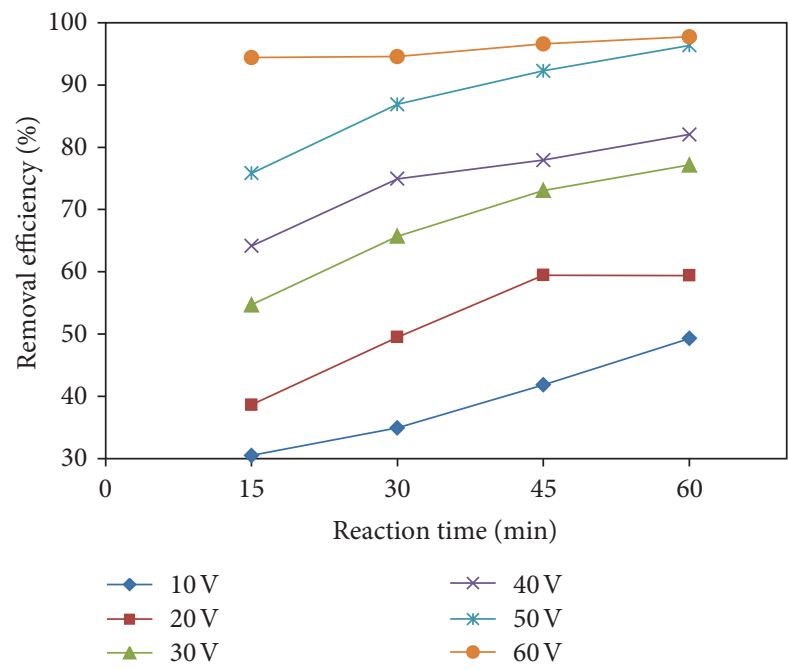

FIGURE 5: Effect of reaction time on TSS removal from dairy wastewater at various applied voltages.

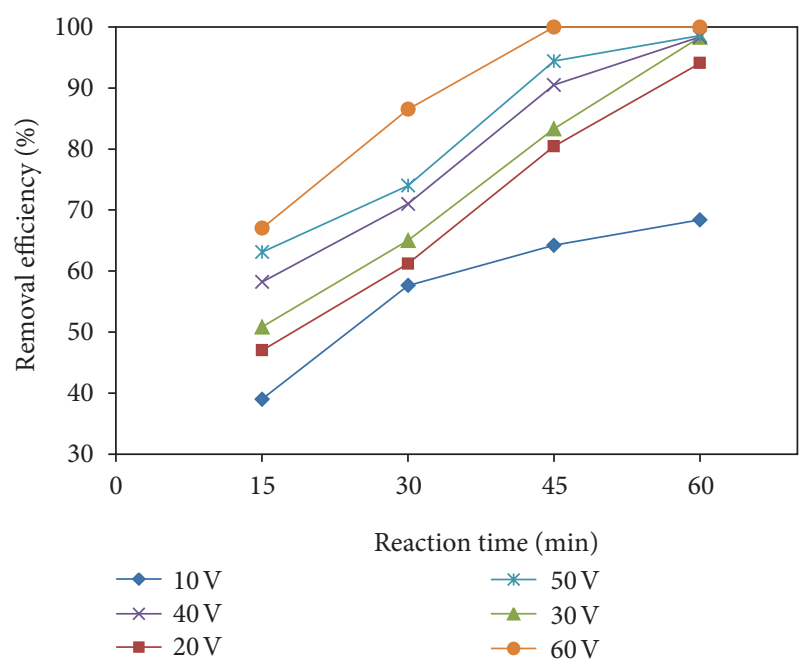

FIGURE 6: Effect of reaction time on TC removal from dairy wastewater at various applied voltages.

consumption were found to increase with increasing the applied voltage as would be expected in any other electrolytic process. An increase in applied voltage from 10 to $60 \mathrm{~V}$ causes an increase in energy consumption from 0.012 to $0.095 \mathrm{kWh} / \mathrm{L}$. Similar trends were seen in the study of Bayar et al. on Poultry slaughterhouse wastewater treatment [42] and Bazrafshan et al. on carwash wastewater treatment by electrocoagulation process [48].

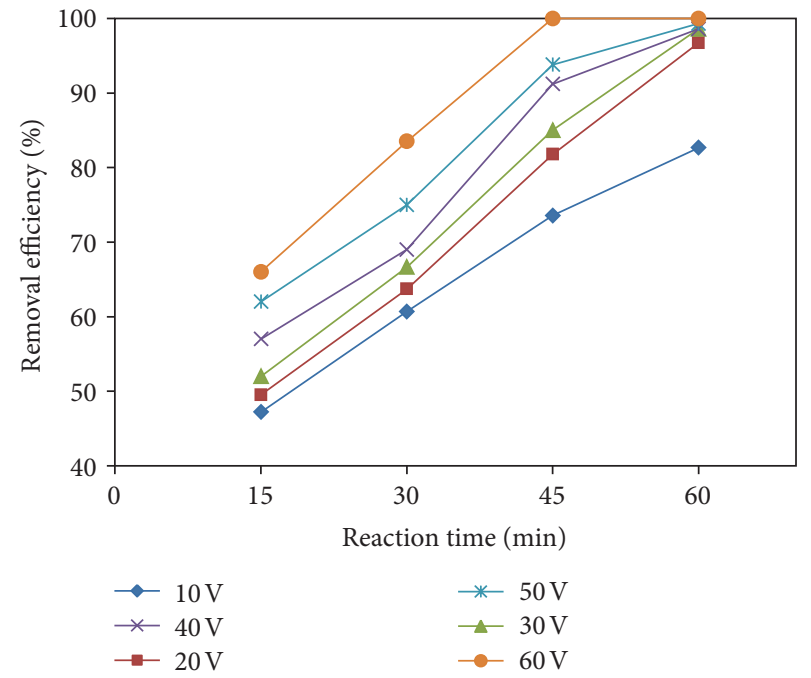

FIGURE 7: Effect of reaction time on FC removal from dairy wastewater at various applied voltages.

Also, as it is presented in this table, electrode consumption varied between 0.249 and $2.672 \mathrm{~g} / \mathrm{L}$. It can be concluded that the higher the voltage of the system applied, the higher the weight of the electrode consumed in the process. On the other hand, an increase in the applied voltage causes a proportional increase of the consumption of electrode by the system. As the table represents, the electrode consumed at $60 \mathrm{~V}$ in the process is much more than that of the process conducted with $10 \mathrm{~V}$. This result is in agreement with the findings of Bazrafshan et al. on slaughterhouse wastewater treatment by electrocoagulation process [18].

\section{Conclusion}

Batch electrocoagulation studies were performed to evaluate the influence of various experimental parameters such as applied voltage and electrolysis time on the removal of pollutants from dairy wastewater. The results of this study have shown the applicability of electrocoagulation in the treatment of real dairy industry wastewater. The treatment rate was shown to increase upon increasing the applied voltage and reaction time. However, increasing the applied voltage caused the energy consumption to increase. Indeed, the highest voltage produced the quickest treatment with an effective reduction of $\mathrm{COD}, \mathrm{BOD}_{5}$, and bacterial indicators (TC and FC) concentration. Consequently, it can be inferred that electrocoagulation is a comparatively suitable process for removal of $\mathrm{COD}, \mathrm{BOD}_{5}$, and other pollutants 
using aluminum electrodes to effectively treat dairy industry wastewater.

\section{References}

[1] D. Orhon, E. Gorgun, F. Germirli, and N. Artan, "Biological treatability of dairy wastewaters," Water Research, vol. 27, no. 4, pp. 625-633, 1993.

[2] M. Vourch, B. Balannec, B. Chaufer, and G. Dorange, "Treatment of dairy industry wastewater by reverse osmosis for water reuse," Desalination, vol. 219, no. 1-3, pp. 190-202, 2008.

[3] B. Sarkar, P. P. Chakrabarti, A. Vijaykumar, and V. Kale, "Wastewater treatment in dairy industries-possibility of reuse," Desalination, vol. 195, no. 1-3, pp. 141-152, 2006.

[4] B. Demirel, O. Yenigun, and T. T. Onay, "Anaerobic treatment of dairy wastewaters: a review," Process Biochemistry, vol. 40, no. 8, pp. 2583-2595, 2005.

[5] T. J. Britz, M. van der Merwe, and K. H. J. Riedel, "Influence of phenol additions on the efficiency of an anaerobic hybrid digester treating landfill leachate," Biotechnology Letters, vol. 14, no. 4, pp. 323-328, 1992.

[6] J. P. Kushwaha, V. C. Srivastava, and I. D. Mall, "Organics removal from dairy wastewater by electrochemical treatment and residue disposal," Separation and Purification Technology, vol. 76, no. 2, pp. 198-205, 2010.

[7] M. W. Heaven, K. Wild, V. Verheyen, A. Cruickshank, M. Watkins, and D. Nash, "Seasonal and wastewater stream variation of trace organic compounds in a dairy processing plant aerobic bioreactor," Bioresource Technology, vol. 102, no. 17, pp. 7727-7736, 2011.

[8] P. N. Dugba and R. Zhang, "Treatment of dairy wastewater with two-stage anaerobic sequencing batch reactor systems-thermophilic versus mesophilic operations," Bioresource Technology, vol. 68, no. 3, pp. 225-233, 1999.

[9] G. Vidal, A. Carvalho, R. Méndez, and J. M. Lema, "Influence of the content in fats and proteins on the anaerobic biodegradability of dairy wastewaters," Bioresource Technology, vol. 74, no. 3, pp. 231-239, 2000.

[10] P. Seesuriyachan, A. Kuntiya, K. Sasaki, and C. Techapun, "Biocoagulation of dairy wastewater by Lactobacillus casei TISTR 1500 for protein recovery using micro-aerobic sequencing batch reactor (micro-aerobic SBR)," Process Biochemistry, vol. 44, no. 4, pp. 406-411, 2009.

[11] B. Montuelle, J. Goillard, and J. B. Le Hy, "A combined anaerobic-aerobic process for the co-treatment of effluents from a piggery and a cheese factory," Journal of Agricultural Engineering Research, vol. 51, pp. 91-100, 1992.

[12] M. Rossini, J. G. Garrido, and M. Galluzzo, "Optimization of the coagulation-flocculation treatment: influence of rapid mix parameters," Water Research, vol. 33, no. 8, pp. 1817-1826, 1999.

[13] N. Z. Al-Mutairi, M. F. Hamoda, and I. Al-Ghusain, "Coagulant selection and sludge conditioning in a slaughterhouse wastewater treatment plant," Bioresource Technology, vol. 95, no. 2, pp. 115-119, 2004.

[14] Ü. Tezcan Ün, A. S. Koparal, and Ü. Bakir Ö囚ütveren, "Hybrid processes for the treatment of cattle-slaughterhouse wastewater using aluminum and iron electrodes," Journal of Hazardous Materials, vol. 164, no. 2-3, pp. 580-586, 2009.

[15] Ü. Tezcan Ün, A. S. Koparal, and Ü. Bakir Ö囚ütveren, "Electrocoagulation of vegetable oil refinery wastewater using aluminum electrodes," Journal of Environmental Management, vol. 90, no. 1, pp. 428-433, 2009.
[16] I. A. Şengil and M. özacar, "Treatment of dairy wastewaters by electrocoagulation using mild steel electrodes," Journal of Hazardous Materials, vol. 137, no. 2, pp. 1197-1205, 2006.

[17] S. Tchamango, C. P. Nanseu-Njiki, E. Ngameni, D. Hadjiev, and A. Darchen, "Treatment of dairy effluents by electrocoagulation using aluminium electrodes," Science of the Total Environment, vol. 408, no. 4, pp. 947-952, 2010.

[18] E. Bazrafshan, F. Kord Mostafapour, M. Farzadkia, K. A. Ownagh, and A. H. Mahvi, "Slaughterhouse wastewater treatment by combined chemical coagulation and electrocoagulation process," PloS ONE, vol. 7, no. 6, Article ID e40108, 2012.

[19] A. S. Koparal and Ü. B. Öütveren, "Removal of nitrate from water by electroreduction and electrocoagulation," Journal of Hazardous Materials, vol. 89, no. 1, pp. 83-94, 2002.

[20] E. Bazrafshan, A. H. Mahvi, and M. A. Zazouli, "Removal of zinc and copper from aqueous Solutions by electrocoagulation technology using iron electrodes," Asian Journal of Chemistry, vol. 23, no. 12, pp. 5506-5510, 2011.

[21] E. Bazrafshan, A. H. Mahvi, S. Nasseri, A. R. Mesdaghinia, F. Vaezi, and Sh. Nazmara, "Removal of cadmium from industrial effluents by electrocoagulation process using iron electrodes," Iranian Journal of Environmental Health Science and Engineering, vol. 3, no. 4, pp. 261-266, 2006.

[22] E. Bazrafshan, A. H. Mahvi, S. Naseri, and A. R. Mesdaghinia, "Performance evaluation of electrocoagulation process for removal of chromium (VI) from synthetic chromium solutions using iron and aluminum electrodes," Turkish Journal of Engineering and Environmental Sciences, vol. 32, no. 2, pp. 59-66, 2008.

[23] E. Bazrafshan, A. H. Mahvi, S. Nasseri, and M. Shaieghi, "Performance evaluation of electrocoagulation process for diazinon removal from aqueous environments by using iron electrodes," Iranian Journal of Environmental Health Science and Engineering, vol. 4, no. 2, pp. 127-132, 2007.

[24] J. Nouri, A. H. Mahvi, and E. Bazrafshan, "Application of electrocoagulation process in removal of zinc and copper from aqueous solutions by aluminum electrodes," International Journal of Environmental Research, vol. 4, no. 2, pp. 201-208, 2010.

[25] E. Bazrafshan, H. Biglari, and A. H. Mahvi, "Phenol removal by electrocoagulation process from aqueous solutions," Fresenius Environmental Bulletin, vol. 21, no. 2, pp. 364-371, 2012.

[26] Ü. Tezcan Ün, A. S. Koparal, Ü. Bakir Öğütveren, and A. Durucan, "Electrochemical process for the treatment of drinking water," Fresenius Environmental Bulletin, vol. 19, no. 9, pp. 1906-1910, 2010.

[27] E. Bazrafshan, K. A. Ownagh, and A. H. Mahvi, "Application of electrocoagulation process using iron and aluminum electrodes for fluoride removal from aqueous environment," E-Journal of Chemistry, vol. 9, no. 4, pp. 2297-2306, 2012.

[28] E. Bazrafshan, H. Biglari, and A. H. Mahvi, "Humic acid removal from aqueous environments by electrocoagulation process using iron electrodes," E-Journal of Chemistry, vol. 9, no. 4, pp. 2453-2461, 2012.

[29] G. H. Chen, "Electrochemical technologies in wastewater treatment," Separation and Purification Technology, vol. 38, no. 1, pp. 11-41, 2004.

[30] N. Adhoum, L. Monser, N. Bellakhal, and J. E. Belgaied, "Treatment of electroplating wastewater containing $\mathrm{Cu}^{2+}, \mathrm{Zn}^{2+}$ and $\mathrm{Cr}(\mathrm{VI})$ by electrocoagulation," Journal of Hazardous Materials, vol. 112, no. 3, pp. 207-213, 2004. 
[31] T. Picard, G. Cathalifaud-Feuillade, M. Mazet, and C. Vandensteendam, "Cathodic dissolution in the electrocoagulation process using aluminium electrodes," Journal of Environmental Monitoring, vol. 2, no. 1, pp. 77-80, 2000.

[32] A. Gurses, M. Yalcin, and C. Dogan, "Electrocoagulation of some reactive dyes: a statistical investigation of some electrochemical variables," Waste Management, vol. 22, no. 5, pp. 491-499, 2002.

[33] X. Chen, G. Chen, and P. L. Yue, "Separation of pollutants from restaurant wastewater by electrocoagulation," Separation and Purification Technology, vol. 19, no. 1-2, pp. 65-76, 2000.

[34] A. G. Vlyssides, D. Papaioannou, M. Loizidoy, P. K. Karlis, and A. A. Zorpas, "Testing an electrochemical method for treatment of textile dye wastewater," Waste Management, vol. 20, no. 7, pp. 569-574, 2000.

[35] O. S. Amuda and A. Alade, "Coagulation/flocculation process in the treatment of abattoir wastewater," Desalination, vol. 196, no. 1-3, pp. 22-31, 2006.

[36] P. Cañizares, M. Carmona, J. Lobato, F. Martínez, and M. A. Rodrigo, "Electrodissolution of aluminum electrodes in electrocoagulation processes," Industrial and Engineering Chemistry Research, vol. 44, no. 12, pp. 4178-4185, 2005.

[37] R. D. Letterman, A. Amirtharajah, and C. R. O. Melia, A Handbook of Community Water Supplies, AWWA, McGrawHill, NewYork, NY, USA, 1999.

[38] P. K. Holt, G. W. Barton, M. Wark, and C. A. Mitchell, "A quantitative comparison between chemical dosing and electrocoagulation," Colloids and Surfaces A, vol. 211, no. 2-3, pp. 233-248, 2002.

[39] N. K. Khosla, S. Venkatachalam, and P. Somasundaran, "Pulsed electrogeneration of bubbles for electroflotation," Journal of Applied Electrochemistry, vol. 21, no. 11, pp. 986-990, 1991.

[40] H. J. Mansoorian, A. Rajabizadeh, E. Bazrafshan, and A. H. Mahvi, "Practical assessment of electrocoagulation process in removing nickel metal from aqueous solutions using iron-rod electrodes," Desalination and Water Treatment, vol. 44, no. 1-3, pp. 29-35, 2012.

[41] C. P. N. Njiki, S. R. Tchamango, P. C. Ngom, A. Darchen, and E. Ngameni, "Mercury(II) removal from water by electrocoagulation using aluminium and iron electrodes," Journal of Hazardous Materials, vol. 168, no. 2-3, pp. 1430-1436, 2009.

[42] S. Bayar, Y. Y. Sevki, A. E. Yilmaz, and S. İrdemez, "The effect of stirring speed and current density on removal efficiency of poultry slaughterhouse wastewater by electrocoagulation method," Desalination, vol. 280, no. 1-3, pp. 103-107, 2011.

[43] N. Drouiche, S. Aoudj, M. Hecini, N. Ghaffour, H. Lounici, and N. Mameri, "Study on the treatment of photovoltaic wastewater using electrocoagulation: fluoride removal with aluminium electrodes-characteristics of products," Journal of Hazardous Materials, vol. 169, no. 1-3, pp. 65-69, 2009.

[44] M. Tir and N. M. Mostefa, "Optimization of oil removal from oily wastewater by electrocoagulation using response surface method," Journal of Hazardous Materials, vol. 158, no. 1, pp. 107-115, 2008.

[45] W. Wan, T. J. Pepping, T. Banerji, S. Chaudhari, and D. E. Giammar, "Effects of water chemistry on arsenic removal from drinking water by electrocoagulation," Water Research, vol. 45, no. 1, pp. 384-392, 2011.

[46] M. Ugurlu, M. H. Karaoglu, and I. Kula, "Experimental investigation of chemical oxygen demand, lignin and phenol removal from paper mill effluents using three-phase three-dimensional electrode reactor," Polish Journal of Environmental Studies, vol. 15, no. 4, pp. 647-654, 2006.

[47] B. Merzouk, B. Gourich, A. Sekki, K. Madani, and M. Chibane, "Removal turbidity and separation of heavy metals using electrocoagulation-electroflotation technique. A case study," Journal of Hazardous Materials, vol. 164, no. 1, pp. 215-222, 2009.

[48] E. Bazrafshan, F. Kord Mostafapoor, M. M. Soori, and A. H. Mahvi, "Application of combined chemical coagulation and electrocoagulation process to carwash wastewater treatment," Fresenius Environmental Bulletin, vol. 21, no. 10, pp. 2694-2701, 2012. 

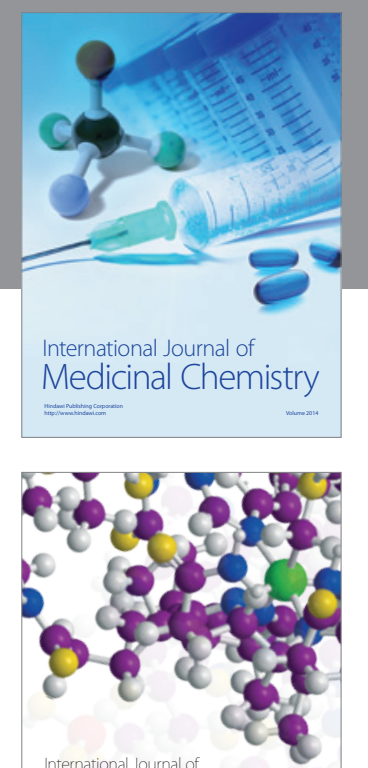

\section{Carbohydrate} Chemistry

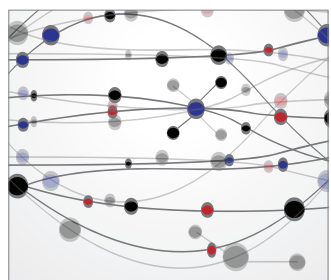

The Scientific World Journal
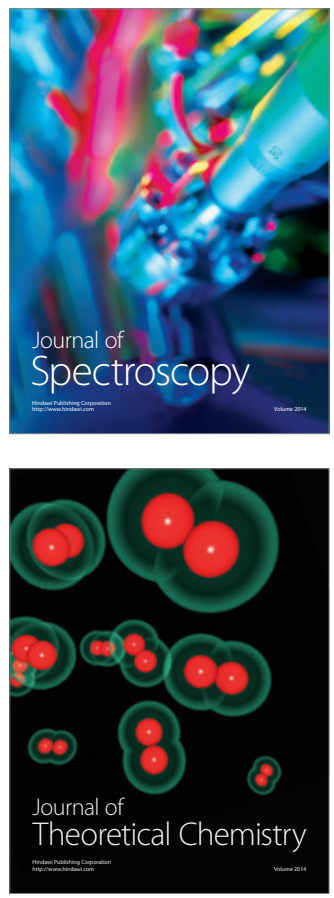
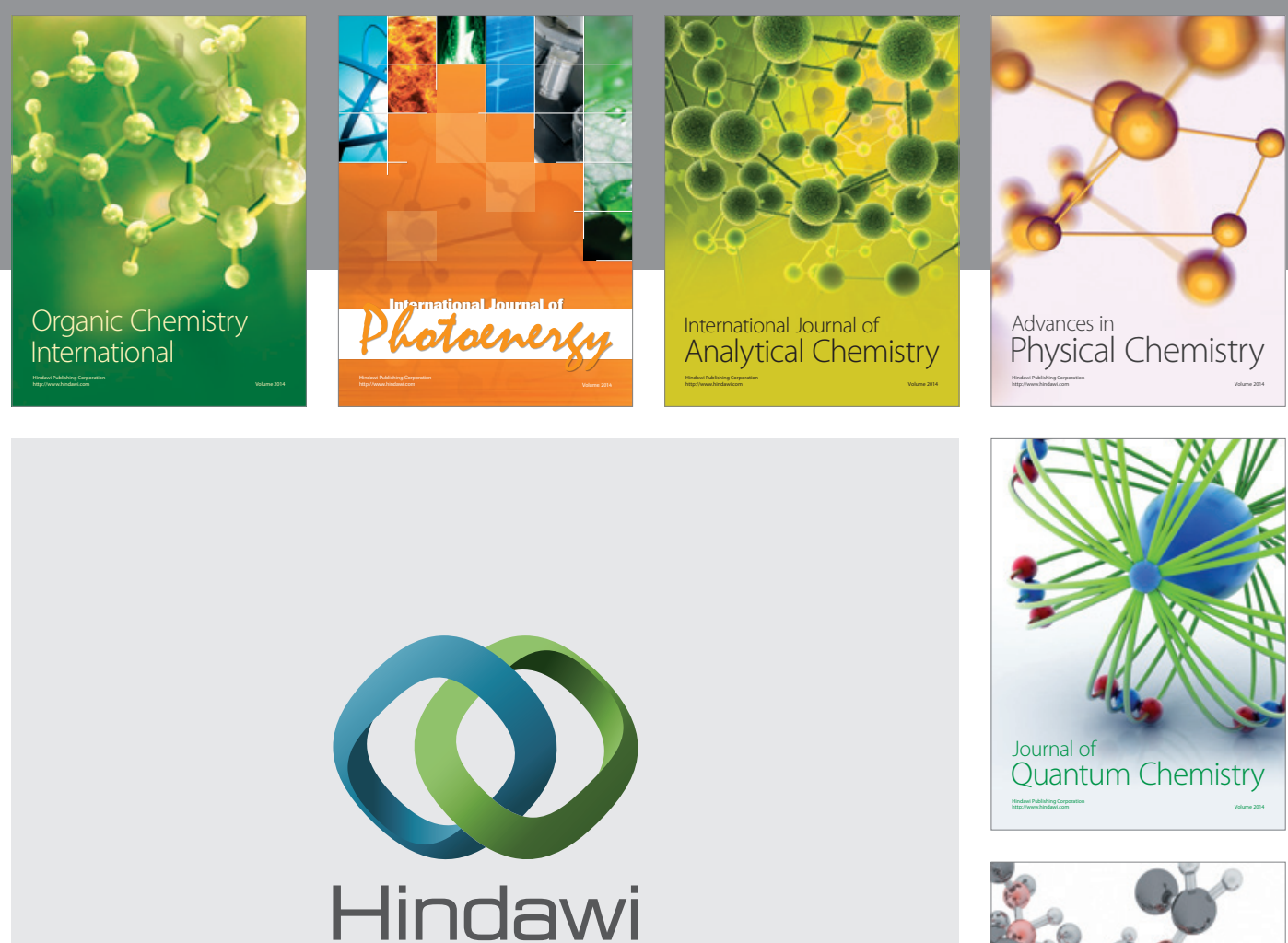

Submit your manuscripts at

http://www.hindawi.com

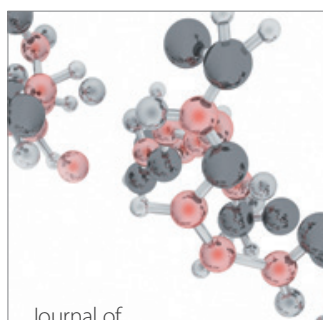

Analytical Methods

in Chemistry

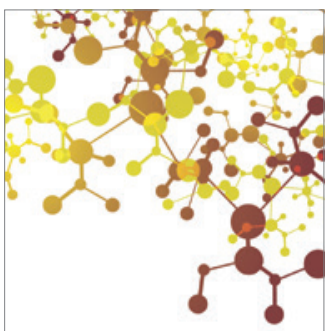

Journal of

Applied Chemistry

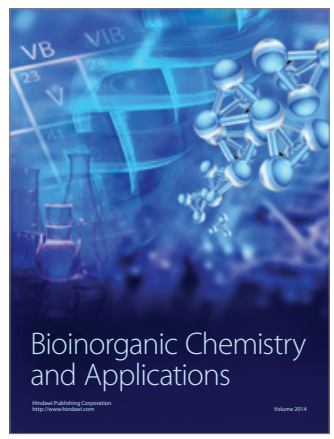

Inorganic Chemistry
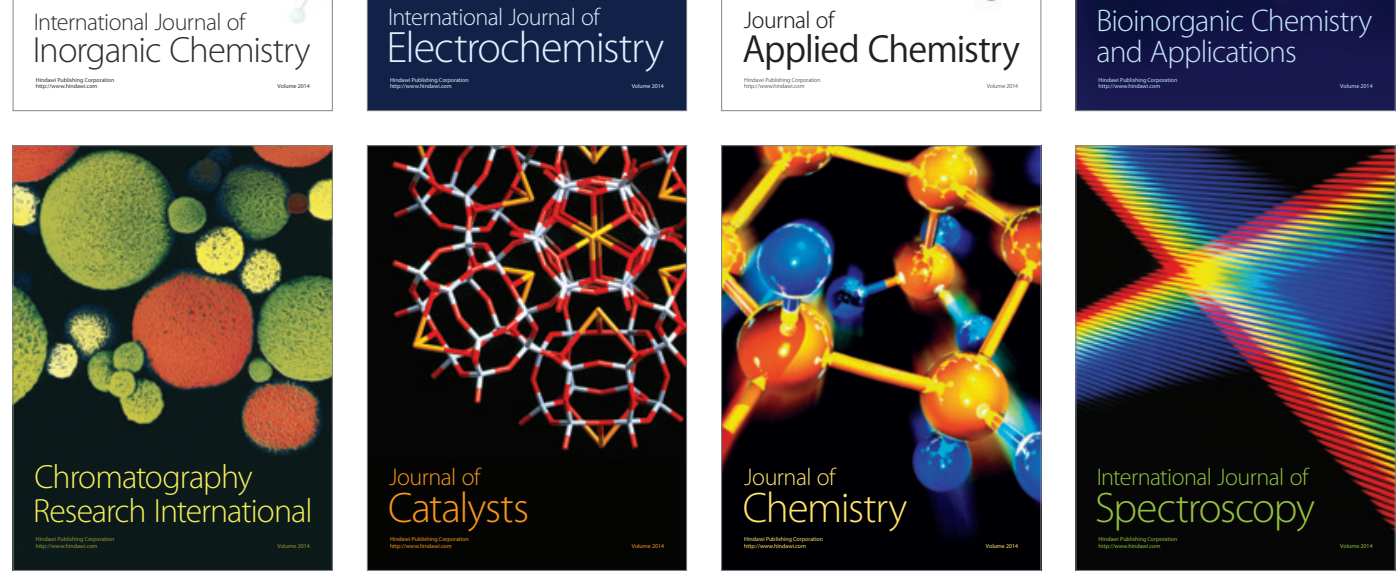